\title{
TEATRO, ÓPERA E CINEMA: SALOMÉ, DE MULHER FATAL A MULHER OBJETO
}

Flavio Felicio Botton*

* galaaz67@gmail.com

Mestre e doutorando em literatura portuguesa

pela FFCH-USP. Professor de Historia da Arte da

Universidade do Grande ABC. Autor de Que enigma

(2012), publicado pela Editora Todas as Musas.

RESUMO: Este trabalho tem por objetivo analisar Salomé como protagonista de três obras diferentes, identificando as particularidades de cada autor e de seu contexto artístico e histórico, em conjunto com a verificação do tratamento que cada um deles confere à personagem feminina.

ABSTRACT: This work aims at analyzing Salome as protagonist in three different works, seeking to identify the characteristics of each author and their artistic and historical context, in conjunction with the verification of treatment that each one of them gives the female character.

PALAVRAS-CHAVE: Salomé, mulher fatal, teatro, cinema, ópera.

KEYWORDS: Salome, femme fatale, film, theater, opera. 
As personagens que representam mulheres fatais sempre fizeram parte da literatura e das artes de muitos países em muitas épocas diferentes, muito embora elas tenham aparecido com maior frequência a partir da segunda metade do século XIX.

Sejam literárias, teatrais, plásticas ou cinematográficas, são muitas as obras a retratar a chamada femme fatale.

Para a criação desse tipo de personagem, servem como ponto de partida nomes históricos, tais como Cleópatra, a sedutora rainha do Egito; Messalina, a cruel e ambiciosa esposa do Imperador Cláudio; Mata Hari, a fascinante espiã dançarina, ou Lucrecia Bórgia, a cruel e libidinosa irmã do tirano Cesare Bórgia. Mas também a literatura criou muitas delas, como a beldade protagonista da sangrenta guerra entre aqueus e troianos, Helena de Tróia. Fazem parte ainda da categoria a mais gananciosa e instigadora das esposas, Lady Macbeth e a personagem título da novela de Prosper Mérimée, que viria a ser a voluptuosa cigana Carmem, da ópera de George Bizet.

O cinema contemporâneo é uma verdadeira fábrica de mulheres fatais. Seria interminável e pouco produtivo listá-las todas, mas, para exemplo, fiquemos com algumas das mais famosas. Sharon Stone interpretou a Catherine Tramell, de Instinto Selvagem (1992) e Rita Hayworth, uma "especialista" em mulheres fatais, nos legou Gilda, do filme homônimo de
Charles Vidor e a Elsa Banister, da película de Orson Welles, A Dama de Xangai (ambos de 1946). Mesmo a cultura pop criou a irresistível Mulher-Gato, por quem o homem morcego parece, às vezes, querer sucumbir.

Algumas das mais instigantes mulheres fatais, no entanto, encontram-se nos textos bíblicos. Sem contar a primeira das mulheres, Eva, temos ainda a filisteia Dalila. Porém, entre elas, a que mais tem motivado os instintos dos artistas é, sem dúvida, a princesa Salomé.

A filha de Herodias foi personagem de dezenas de quadros desde os mais antigos como a têmpera sobre madeira de Lucas Cranach, o velho (1472-1553), com o título Salome com a cabeça de São João Batista, até trabalhos mais recentes como a estimulante tela de Pierre Bonnaud (1865-1930), Salomé, passando pelos grandes nomes de Botticelli, Ticiano, Caravaggio e Moreau, todos eles autores de uma tela em que aparece a princesa ou o resultado de seus atos.

Em versos, Stéphane Mallarmé transformou o mito em teatro e fez a sua Hérodiade (1864). O poeta simbolista português Eugênio de Castro também compôs a sua Salomé(1896), a quem "os reis do norte e sul virão beijar os pés em longas comitivas".

$\mathrm{Na}$ prosa, temos alguns exemplos com J. K. Huysmans que, em seu Às avessas (1884), fala com deslumbre da princesa, enquanto Gustave Flaubert, em seu Três Contos (1877)

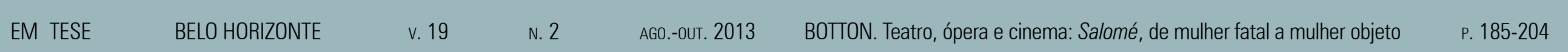

\section{Crítica Literária, outras Artes e Mídias}


dedica um a Herodias e Jules Laforgue, que faz o mesmo em suas Moralités légendaires (1887).

Por fim, mas não esgotando a lista, em 1896, sobe a cena Salomé, de Oscar Wilde, peça inspirada na conhecida passagem bíblica narrada por São Mateus e São Marcos. Nove anos depois, fascinado com o trabalho de Wilde, Richard Strauss, executando uma de suas obras mais ousadas, adapta a peça para uma ópera que escandaliza as plateias. Já em 1953, o filme Salomé, dirigido por William Dieterle, tendo Rita Hayworth como personagem título, leva às telas do cinema a história da princesa. Tendo em vista um pequeno recorte nesse imenso universo, este trabalho tem por objetivo comparar a protagonista dessas três últimas obras citadas, identificando as particularidades de cada autor e de seu contexto artístico e histórico, em conjunto com a análise do tratamento que cada um deles confere à personagem feminina.

\section{PARA A LEITURA DAS PERSONAGENS FEMININAS}

Antes disso, no entanto, procuraremos apresentar algumas questões sobre as relações de gêneros em duas perspectivas, sendo que ambas partem do princípio comum que pressupõe não existirem relações sociais, na nossa cultura que não sejam de exploração ou de conflito.

Primeiramente, temos a visão a que chamaremos de "biológica" ou "sexual"; e, em seguida, a "social".
A primeira tese apoia-se, em grande parte, nas diferenças biológicas e fisiológicas existentes entre os gêneros como ponto de partida para explicar o posicionamento da mulher na sociedade.

Seguindo essa linha de pensamento, podemos dizer que o grande desafio do homem, desde os primórdios de sua existência, sempre foi o confronto com o desconhecido. E o maior de todos os "desconhecidos" que ele enfrentou, desde a infância da humanidade, foi o enigma do corpo feminino, capaz da geração.

O misterioso corpo, capaz de "expelir" um outro ser humano, teria, portanto, gerado um medo da devoração. Ou seja, se esse indivíduo é capaz de "pôr para fora" talvez ele seja também capaz de "pôr para dentro". Essa situação, segundo Camille Paglia (1991:24), seria uma metaforização do ato sexual, em que o "macho sai com menos do que ao entrar".

Entre outros elementos, esse medo teria dado origem a diversos mecanismos cujos objetivos seriam a tentativa de dominação e de repressão. A mesma Paglia refere-se à associação da mulher com a natureza, ainda na pré-história da humanidade. Aqui, a mulher e a natureza são colocadas no mesmo patamar do ignoto. Porém, mais tarde, na sociedade grega, cria-se um primeiro mecanismo de repressão que seria a tragédia: "A mulher introduz crueldade bruta nas 
tragédias porque é ela o problema que o gênero tenta corrigir” (Paglia, 1991:18).

Mas, ainda segundo Paglia, o mais refinado dos modos de repressão foi a transferência do culto pagão da terra, pelo culto cristão do céu. Isso acaba por significar uma transferência do culto do ventre ( $=$ terra, feminino) para o culto da cabeça (= racional, masculino)

E assim seguem-se e proliferam-se diversos modos de dominação e repressão que chegam até os dias de hoje e que se aperfeiçoam no cinema.

Dessa forma, podemos dizer, resumidamente, que o conflito e a tentativa de dominação são frutos daquilo que, nas palavras de Camille Paglia, está escondido nas "entranhas da terra”, na natureza, identificado com o feminino.

A segunda visão a que nos referimos, a "social", teria por base que a exclusão da mulher se deve à estrutura patriarca da família burguesa e capitalista, em que a mulher está em segundo plano, não fazendo parte da facção ativa que controla o capital ou os meios de produção e nem mesmo participa como força de trabalho (fato que só irá começar a se modificar no período da Segunda Guerra Mundial). De acordo com essa hipótese, a mulher é identificada, muitas vezes, como objeto de status que, quanto mais adornada, mais recebe valor. Dentro deste sistema, a sua possibilidade de realização tem sido relegada, situação que obviamente está há muito tempo se alterando, unicamente ao casamento.

Vejamos então como essas relações se dão nas obras escolhidas para objeto desse trabalho procurando identificar, além das questões relacionadas à personagem feminina, a femme fatalle, as particularidades de cada autor e de seu contexto artístico e histórico. Para isso, propomos uma leitura analítica e comparativa entre alguns aspectos da peça de Oscar Wilde, Salomé, da ópera homônima de Richard Strauss, e do filme de mesmo nome de William Dieterle, protagonizado por Rita Hayworth. Vale destacar que a ópera de Strauss foi baseada na peça de Wilde, mas o roteiro do filme, assinado por Harry Kleiner é um texto autônomo, não foi baseado nem na peça nem na ópera. Em todos os casos, percebe-se que o episódio bíblico de Salomé foi apenas ponto de partida para a criação das obras que, como veremos, seguem caminhos, às vezes mais, às vezes menos, diferentes.

\section{SALOMÉ NO TEATRO}

Oscar Wilde foi, além de dramaturgo de excelência, poeta e romancista. Uma das mais extravagantes personalidades do universo literário, equiparável apenas a Lord Byron, Wilde já era um artista reconhecido quando o moralismo excessivo da sociedade vitoriana caiu-lhe sobre os ombros com todas as forças.

\section{Crítica Literária, outras Artes e Mídias}


Em 1890, entre seus trabalhos publicados já estava o romance, $O$ retrato de Dorian Gray, que, apesar de ser único da sua lavra, daria ao autor um lugar na galeria dos grandes clássicos da literatura mundial, além de ser fonte de inúmeras adaptações para o cinema.

Em 1892, Wilde trabalha em sua Salomé, personagem que o encantava e cujas descrições apareciam sempre em suas conversas com amigos. O dramaturgo tinha conhecimento de diversas versões da princesa retratada nas artes plásticas, mas manifestava preferência pela versão de Gustave Moreau, Salomé dançando para Herodes (óleo sobre tela, 1876, Louvre)

Wilde havia resolvido escrever a peça, não em sua língua natal, mas em francês, para que Sarah Bernardt, atriz mundialmente famosa, assumisse o papel da princesa.

A peça é proibida de ser encenada em Londres, mas estreia com sucesso em Paris e em Berlim em 1893. Sua versão impressa será publicada com expressivas ilustrações de Audrey Bearsdley, em 1894.

No entanto, em 1895, Wilde sofre um duro golpe com uma condenação a cinco anos de trabalhos forçados, por comportamento imoral. Após essa condenação, que o levaria a prisão até 1897 , a vida do dramaturgo mudou radicalmente.

Seus trabalhos como De profundis (1897), A balada do cárcere de Reading (1896), ou mesmo a peça The Importance of
Being Earnest (1895) mostram um homem bastante cético em relação ao seu tempo e à sua sociedade.

Wilde faleceu apenas três anos após sair da prisão. Seu corpo foi trasladado mais tarde para o Cemitério Pere Lachaise, em uma sepultura que está sempre coberta por marcas de batom, beijos que admiradores deixam como homenagem ao artista.

A personagem que tanto o enfeitiçava, no Evangelho de São Mateus (14, 6-12), é assim descrita pelo apóstolo:

No dia do aniversário de Herodes, a filha de Herodias dançou diante de todos e agradou tanto a Herodes que ele prometeu, jurando, dar-lhe tudo quanto pedisse. E ela, instigada pela mãe, lhe disse: "Dá-me agora mesmo, numa bandeja, a cabeça de João Batista”. O rei ficou triste, mas devido ao juramento e à presença dos convidados, ordenou que lhe dessem a cabeça. Mandou, pois, degolar João na cadeia. Sua cabeça foi trazida numa bandeja e dada à jovem, que a levou à sua mãe.

A Salomé bíblica difere muito da Salomé de Wilde, tanto na riqueza de detalhes, quanto nas características da personagem principal. Vejamos então alguns destes fatores diferenciais.

Partindo da passagem bíblica, Oscar Wilde recria a história de Salomé com modificações significativas. Como por exemplo, no texto de Wilde, encontramos algumas personagens

\section{Crítica Literária, outras Artes e Mídias}


não citadas em São Mateus. As mais significativas destas são o jovem sírio, capitão das guardas de Herodes Antipas, e o pagem de Herodias.

Estas personagens serão cruciais para a caracterização de Salomé que, como observaremos em seguida, é, por sua vez, oposta à Salomé dos evangelhos, e ainda, no seu diálogo, estabelecem uma espécie de "prolepse", ou antecipação, do final do drama.

No diálogo inicial, duas comparações devem ser destacadas:

Pajem: Olha para a lua, homem! Vê como está estranha! Parece uma mulher erguendo-se do túmulo, uma mulher morta; é como se toda ela se voltasse para a contemplação das coisas mortas.

Sírio: A lua tem um estranho olhar. É tal qual a pequena princesa que traz um véu amarelo e cujos pés são de prata [...]

Pajem: A lua parece uma mulher morta [...].

(WILDE, 1989: 21-22)

Repare-se que o Pajem compara a lua com uma mulher morta e, logo em seguida, como uma resposta, o Sírio associa a mesma imagem com a princesa Salomé. A associação entre Salomé e a lua segue até o fim do texto, quando, logo antes da morte da princesa, ordenada por Herodes, aparece a rubrica:
"(Os escravos apagam as luzes; as estrelas desaparecem; uma grande nuvem oculta a lua. O teatro fica completamente escuro. O tetrarca sobe as escadas)" (WILDE, 1989: 108).

A lua como elemento que traz a sensação de morte, ou mesmo que a personifica, irá continuar também nas falas de Herodes, sempre associada a um elemento feminino ("Parece uma mulher louca, uma doida, à cata de amantes"). (WILDE, 1989: 57)

Visão algo diferente da lua, aparecerá apenas nas falas da própria Salomé, que faz daquele astro seu espelho: "Parece uma pequena moeda d'oiro, uma florzinha de prata. A lua é fria e casta. Estou certa que é virgem. Tem a beleza das virgens... nunca se corrompeu! Nunca se entregou aos homens, como as outras deusas". (WILDE, 1989: 35)

E ainda, como elemento que estabelece a ligação da princesa com o profeta Iokanaam, e associa ambos o mesmo destino: Salomé: "Como é branco! É como uma estátua de marfim, como uma imagem de prata. Estou certa de que é casto como o lua. Parece um raio de luar [...]" (WILDE, 1989: 45).

Além desta função de antecipação, a personagem do jovem sírio é fundamental para a construção da personagem de Salomé. A postura que a princesa toma frente ao capitão das guardas revela-nos já o caráter indiferente, orgulhoso e cheio de caprichos, que a levará a pedir a morte do profeta.

\section{Crítica Literária, outras Artes e Midias}


Ou seja, a princesa despreza todas as falas do Sírio a ela dirigidas; apenas conversa com o capitão quando a ela convém; e, por fim, não leva em conta os apelos do jovem Sírio, nem tampouco aos perigos que seu pedido o exporia. Além disso, temos, como mais uma expressão deste caráter, a cena do suicídio, em que o Sírio cai entre Salomé e o profeta e ela continua a dirigir-se a João Batista como se nada houvesse ocorrido.

Outros elementos vêm auxiliar na construção da personagem. Também como exemplo, podemos tomar a cena em que Salomé ordena aos guardas que tragam o profeta. Nesta sequência de frases da princesa, em meio às negativas vãs dos guardas, nota-se uma progressão que pode ser resumida através dos verbos, demonstrativa do caráter autoritário da princesa: "Seria capaz de falar-lhe / Desejo falar-lhe / Quero / Tragam à minha presença esse profeta!” (WILDE, 1989: 38)

Sendo assim, fica clara a diferença entre a Salomé de Oscar Wilde e a personagem bíblica. Vimos que a Salomé de São Mateus é "instigada pela mãe" e, ao receber a cabeça do profeta, entrega-a a Herodias, colocando-se desta forma de maneira quase que passiva diante dos acontecimentos e submissa diante da mãe.

Já a personagem de Wilde, além de seduzir o Sírio e o próprio tetrarca, despreza a presença da mãe e ainda pede a cabeça do profeta por motivos muito particulares. O caráter da princesa, não descrito no evangelho, é preenchido por Wilde como o da própria mulher fatal: impiedosa tanto aos apelos do Sírio, do Profeta, como do próprio tetrarca de Jerusalém, autoritária, sedutora, dissimulada, e, ao fim de tudo, não hesita em pedir a morte daquele que a recusou.

É interessante destacar que a peça centraliza-se no momento em que a princesa Salomé atinge a sua maturidade sexual, que é simbolizada justamente pela lua: "Sua maturidade sexual (da mulher) significa casamento com a lua, crescendo e minguando nas fases lunares" (PAGLIA, 1991: 21).

Mais dois fatos devem ser destacados nesta peça: as ofertas de Herodes e o pedido de Salomé. Esse conjunto é o que vai tornar Salomé uma personagem muito cara aos simbolistas e decadentistas, tais como Wilde e os outros já citados Mallarmé, Eugênio de Castro e Huysmans. Ao pedir a cabeça do profeta, a personagem de Salomé põe em prática, e em grande estilo, o chamado "ato gratuito":

A cabeça de João Batista entra em jogo, ao invés de riquezas, por nenhuma razão plausível, mesmo se considerando que, em Wilde, a vingança é perpetrada por causa de um amor não correspondido. De um modo ou de outro, o ato é gratuito: com o crime, ela não obtém coisa alguma em troca. (GOMES, 1990: 68)

\section{Crítica Literária, outras Artes e Midias}


1. Podemos mesmo observar uma alegoria do período vitoriano, extremamente conservador no que diz respeito aos costumes, que logo em seguida, como se viu, irá condenar o próprio Wilde por práticas homossexuais.
E, mais ainda, reforça a gratuidade e o desprezo ao utilitarismo e aos bens materiais, tão em voga no momento de ascensão burguesa mesquinha e tacanha, inconciliável com os ideais artísticos dos simbolistas e decadentistas. Salomé é alçada à posição de símbolo dos artistas de uma época, por ser: "algo contrário ao interesse, contrário ao lucro e àquilo que fazia as alegrias da sociedade mercantil” (GOMES, 1990: 68).

Salomé rompe com o poder financeiro, social e político do Tetrarca Herodes, da mesma forma que o artista decadentista rompe com a arte e com o público burgueses. No contexto social da peça, Salomé é punida por demonstrar essa independência em relação à vontade do patriarca e ainda por não satisfazer ao padrão de mulher aceito pela sociedade burguesa, capitalista e patriarcal ${ }^{1}$.

Já na hipótese "sexual", revela-se novamente o medo do poder oculto feminino. Repare-se então que Herodes manda executar Salomé para que ele mesmo não viesse a ter o fim que os outros que olharam para ela (o Sírio e o Profeta) tiveram, ou seja, mata a princesa para que ela não o mate. Também associado a essa hipótese, temos a cena em que Salomé beija a cabeça decapitada do Batista. A cabeça cortada nos remete a ação de "tirar a razão" ou "aflorar o instinto". E o ato de beijar a boca morta traz analogicamente a questão já mencionada da devoração.

EM TESE
BELO HORIZONTE
Destacamos então três aspectos da Salomé, de Oscar Wilde: a mulher que não se encaixa nos padrões sociais burgueses; a mulher fatal, que não se encaixa no paradigma patriarcal e, finalmente, como uma personagem emblemática da rebeldia e do desajuste social do artista simbolista / decadentista.

\section{SALOMÉ NA ÓPERA}

Desde muito cedo envolvido pelo universo musical, pois seu pai era músico, Strauss foi um dos grandes nomes da música erudita no romantismo tardio.

Verdadeiro agitador cultural, além de instrumentista, regente e compositor, foi diretor da Ópera de Viena. Sua gama de trabalhos, assim como a sua produtividade, é bastante grande e envolve desde os poemas sinfônicos, alguns deles baseados em obras literárias, como é o caso de Macbeth (1886-88) e Don Juan (1889), até as peças solísticas, passando pela operística, em que encontramos, além de outras, uma série de nomes de mulheres, o que mostra certa predileção de Strauss pelas protagonistas femininas, tais como Elektra (1909), Ariadne na Ilha de Naxos (1916), A Mulher sem Sombra (1918), A Helena Egípcia (1928), Arabella (1933), A Mulher Silenciosa (1935), Daphne (1938) e Os Amores de Danae (1952).

Porém, a peça que mais escandalizou as plateias foi Salomé. Conta-se que a soprano escalada para o papel principal recusava-se a executar certos atos exigidos pela personagem

\section{Crítica Literária, outras Artes e Mídias}


da princesa "por ser uma mulher correta". Mesmo em Nova York, o choque foi tão intenso que a ópera teve de ser retirada de cartaz após a primeira récita (KOBBÉ, 1997).

O alemão Hedwig Lachmann foi quem traduziu a peça de Oscar Wilde para que Strauss pudesse convertê-la em ópera, da qual é autor não só da música, mas também do libreto, que irá estrear em Berlim em 9 de dezembro de 1905.

Baseada fielmente na peça de Oscar Wilde, o texto traz, por conta do ajuste de linguagem, muitas supressões, poucas alterações e alguns acréscimos.

Os mesmos personagens, Narraboth (o capitão sírio), o Pajem de Herodias e alguns soldados, abrem a ópera observando alternadamente, ora a lua, ora a princesa Salomé, no terreiro do palácio de Herodes, que está a receber convidados para uma festa. A ópera abriu mão de uma peça de abertura introduzindo-se diretamente pelo diálogo do capitão da guarda com o pajem de Herodias.

As menções ao símbolo feminino da lua são mantidas e até mesmo evidenciadas pela música e pelo libreto de Strauss. A sonoridade das primeiras cenas é de uma expressividade bastante sombria, mas se altera sensivelmente nas falas de Iokanaan, o profeta que está em uma cisterna, ainda invisível para o público.

Salomé entra na segunda cena, aproximando-se do local onde estão os guardas, pois não aprecia em nada as companhias escolhidas por Herodes, sentindo-se bem, como os bons românticos, ao ar livre, onde o ar é doce e pode-se respirar verdadeiramente.

A presença da princesa desnorteia o pobre capitão que só tem olhos para ela. Salomé, no entanto, ouve a voz de Iokanaan, mais uma vez em um corte de tom solene na melodia, e demonstra a vontade de conhecê-lo. Os soldados tentam dissuadi-la de seu intento, mas ela interrompe a fala dos subalternos por mais de uma vez, mostrando desprezo por todos.

Como na peça de Wilde, Salomé se expressa em um crescendo de autoritarismo que é evidenciado pelos versos: "É meu desejo falar com ele [...] quero falar com ele [...] traga cá para fora o profeta, quero vê-lo" (STRAUSS, 2011: 24).

Ao ver a resistência dos soldados, a princesa usa a sedução, dirigida especialmente ao sírio, para que seu desejo seja satisfeito, sem se importar com as consequências que o capitão irá sofrer, pois o próprio Herodes proibiu que qualquer pessoa se encontrasse com o profeta.

Salomé: Você fará isso por mim, Narraboth

Deixarei cair uma pequena flor

Para você, uma pequena e verde florzinha $[. .$.

Ah! Sabe muito bem

Que fará o que lhe peço!

\begin{tabular}{|c|c|c|c|c|c|c|}
\hline EM TESE & BELO HORIZONTE & v. 19 & N. 2 & AGO.-OUT. 2013 & BOTTON. Teatro, ópera e cinema: Salomé, de mulher fatal a mulher objeto & P. 185-204 \\
\hline
\end{tabular}

\section{Crítica Literária, outras Artes e Mídias}


(forte)

Sei que fará.

(STRAUSS, 2011: 25)

O capitão sucumbe aos desejos da princesa e surge em cena Iokanaan que, ao começar a cantar a sua parte, faz com que a música assuma um tom rigoroso e solene, assegurado pelos metais que, em alguns momentos, acompanham em uníssono as palavras do profeta.

Segundo Kobbé, “a estranha e sombria silhueta de Iokanaan, cheio de nobreza mesmo nos farrapos do cativeiro, emerge do poço ao som de um extenso comentário orquestral (que inclui um enunciado do tema a ele associado)" (KOBBÉ, 1997:554).

O diálogo entre Salomé e Iokanaan, intercalado por algumas intervenções de Narraboth, é de muita riqueza expressiva, em que se percebem três climas distintos. Salomé, nas três vezes em que fala de sua paixão pelos olhos, pelo corpo e, por último, pelos cabelos do profeta, assume um tom de alto lirismo apaixonado, com a mais "magnífica das caracterizações (em que) cada uma de suas constantes reviravoltas emocionais é refletida na música" (KOBBÉ, 1997: 555). Iokanaan, em todas as oportunidades, corta as palavras da princesa com um tom forte e, mais uma vez solene, procurando rechaçá-la. Entre eles, aparece o desespero do jovem sírio ao ver a sua desejada princesa declarar-se tão cruamente a um preso, o que acaba por culminar com o seu suicídio, que não causa nenhuma reação na princesa, embora, como na peça de WIlde, ele caia morto aos pés dela.

Descem ao terreiro Herodes, Herodíades e seu séquito e "raramente a luxúria obsessiva terá sido retratada com tal força quanto na música de Herodes, que a cada passo deixa implícitos o medo e a decadência da personagem" (KOBBÉ, 1997: 555). Herodes pede a Salomé que se aproxime dele, utilizando-se de apelos aos sentidos mais primitivos, como a sede e a fome. Interessa notar o fascínio que o rei tem pela enteada, mas, mais ainda, uma das expressões em particular, em que Herodes diz:

Salomé, venha cá, coma comigo destas frutas Agrada-me tanto ver numa fruta a marca Dos seus pequenos e alvos dentes.

Morda só um pouco

Só um pouquinho desta fruta,

Que eu depois comerei o resto

\section{(STRAUSS, 2011: 31).}

O rei, em sua desenfreada busca por sensações, deixa cegar-se pela luxúria e acredita que está no comando da situação.

\section{Crítica Literária, outras Artes e Midias}


Isso faz com ele brinque com o símbolo daquilo que deveria mais temer, o instrumento da já mencionada devoração, os dentes da mulher fatal, como se irá confirmar ao fim da peça.

Junto com o séquito de Herodes vem um grupo de judeus que, bizantinamente, discutem questões relacionadas com o profeta. Para acentuar a desordem e o desacordo da corte de Herodes, Strauss faz com que se repitam as falas dos judeus, enquanto na peça de Wilde elas ocorrem apenas por uma vez. As falas são sobrepostas e tumultuadas e terminam com o desesperado pedido de Herodiades para que se calem. Porém, quando isso acontece, surge calma e solene a voz de Iokanaan, para desalento da rainha. Ainda na sequência, os nazarenos falam dos milagres realizados por Cristo.

Para afastar essas discussões, o tetrarca da Judéia pede a Salomé que dance para ele. Como se sabe, devido à resistência da princesa, Herodes promete dar a ela o que ela desejar em troca da dança, mais uma vez para o desespero de Herodiades.

Salomé por fim aceita o juramento de Herodes que, antes da dança começar, livra-se da coroa: "Esta coroa me aperta. / Estas rosas são como fogo / (desfaz-se da coroa e atira-a sobre a mesa)" (STRAUSS, 2011: 38). Além de símbolo de dignidade e poder, a coroa visa realçar a cabeça, ou seja, a racionalidade de quem a usa. Ao desprezar a coroa, Herodes revela-se, sem perceber, pronto para se entregar ao poder sensual de Salomé.
Segue-se ao aceite de Salomé o mais célebre episódio da ópera, a dança dos sete véus, que causou problemas aos primeiros encenadores da obra de Strauss, pois ela é "bastante longa e extremamente extenuante para uma prima donna que ainda tem pela frente os momentos mais difíceis da sua parte vocal. $\mathrm{Na}$ estreia da ópera, a dança foi confiada a uma bailarina, e uma vez terminada a cantora surgiu novamente entre o coro" (KOBBÉ, 1997: 555).

Após a dança, a princesa demonstra, assim como já se viu, toda a gratuidade de seu ato, toda a vaidade de seu desejo, todo o seu desprezo pela mãe e pelos bens materiais.

Herodes: O que quer ter, Salomé?

Salomé (levanta-se sorrindo):

A cabeça de Iokanaan.

Herodes (sobressaltando-se): Não, não!

Herodiades: Ah! Bem dito, minha filha,

Bem dito.

Herodes: Não, não, Salomé! [...]

Não ouça a voz da sua mãe

Sempre dá maus conselhos. [...]

Salomé: Não presto atenção no que diz minha mãe.

Só para meu prazer,

A cabeça de Iokanaan quero ter,

Numa bandeja de prata

(STRAUSS, 2011: 39).

\section{Crítica Literária, outras Artes e Midias}


E, mais uma vez, desenha-se a figura autoritária que, como uma criança mimada, não argumenta nem refuta os argumentos contra a morte do profeta, apenas exige, completamente dominada pelo princípio do prazer, aquilo que ela deseja. "Peço [...] Exijo [...] Dê-me [...] Quero a cabeça de Iokanaan [...]” (STRAUSS, 2011: 40 e 41).

Vencido, o tetrarca, "desesperado, deixa-se cair bruscamente na cadeira" e "(com voz débil) Dê-lhe o que pede! / É filha de sua mãe” (STRAUSS, 2011: 43).

A chocante cena final compõe-se de um longo monólogo de Salomé segurando a cabeça decepada de Iokanaan e a princesa retoma justamente a questão da devoração, nos mesmos termos que já haviam sido utilizados ingenuamente por Herodes:

\section{Ah! Não queria deixar}

Que eu beijasse a sua boca, Iokanaan!

Pois bem, agora eu a beijarei.

Quero mordê-la com meus dentes

Como se trinca um fruto maduro

[...]

Pois bem! Eu ainda vivo, e você está morto,

E sua cabeça me pertence.

(STRAUSS, 2011: 43).
A boca do profeta é assimilada a um fruto pronto a ser colhido e consumido, ou seja, devorado. Da mesma forma, o símbolo que, como vimos, refere-se tanto ao racional quanto ao culto cristão, é decepado e dominado impetuosamente por Salomé.

O beijo dado pela princesa, ponto alto da ópera, é também a parte mais lírica da musicalidade apresentada, o que causa um efeito de profunda aversão, posto que esteja associada ao momento mais hediondo do entrecho. A música na cena final "transcende as implicações dramáticas do texto, composta - por assim dizer do ponto de vista da personagem - como uma espécie de Liebestod psicopático" (KOBBÉ, 1997: 555).

Ao fim de cena sinistra, retoma-se a identidade entre Salomé e a lua nas falas de Herodes e nas didascálias:

(a lua desaparece)

Herodes: Ocultem a lua, ocultem as estrelas! [...]

(A lua reaparece e ilumina Salomé)

Matem essa mulher!

(Os soldados caem sobre Salomé e esmagam-na com os escudos)

(STRAUSS, 2011: 44).

A lua não é o único, mas é o mais significativo dos símbolos acentuados pela adaptação de Strauss. Salomé, por exemplo,

\section{Crítica Literária, outras Artes e Mídias}


ao referir-se ao profeta, faz uso de uma série de elementos que remetem sempre à pureza, tais como "branco", "lírios" e "neve" (STRAUSS, 2011, p 27). Narraboth, completamente equivocado, como em todos os seus atos, vê na princesa a "pomba de todas as pombas" (STRAUSS, 2011: 29), que nos remete ao Espírito Santo da iconografia cristã, mas também à pureza e à moderação, duas características inconciliáveis com a verdadeira Salomé.

Mas, como já foi visto no texto de Wilde, a lua é um símbolo de grande importância, pois se conecta fundamentalmente ao feminino. $\mathrm{O}$ fato de possuir diferentes fases e de mudar o seu formato com o tempo levou a associação do satélite terrestre com a inconstância, assim como ao transitório e ao perecível. Mesmo no tarô, a lua está presente e remete a aspectos negativos, tais como solidão, tristeza, fanatismo e falsidade. É ainda um astro que exerce influência sobre vários aspectos cotidianos dos homens, entre os mais conhecidos, sobre as marés e sobre o corte de alguns tipos de madeira, que só deve ser feito em dias de lua minguante. Assim, mesmo distante, deve ser temido e respeitado, caso contrário desastres podem acontecer.

É nesse sentido que a conexão entre Salomé e a lua deve ser lida. A princesa não é mais uma menina, é uma mulher que alcança, na presença de Iokanaan, a sua maturidade sexual. A inobservância dessa situação leva os circunstantes à perdição, seja do seu poder, como a coroa de Herodes, seja de sua racionalidade, como a cabeça do profeta (Paglia, 1991).

Mais uma vez, a mulher fatal não se encaixa nem no paradigma patriarcal nem no materialista e muito menos ainda no ambiente religioso descrito pela ópera (assim como pela peça) em que, como se afirmou antes, o culto cristão da cabeça, em franca ascensão, substitui o culto do ventre. Assim, ela precisa ser eliminada para que não exerça o seu poder sobre os outros. Por conta desse medo do feminino, os soldados que atacam a princesa não utilizam as suas espadas, símbolos fálicos do poder masculino, mas escondem-se por detrás de seus escudos protetores, esmagando Salomé.

\section{SALOMÉ NO CINEMA}

O cinema, desde cedo, foi bastante pródigo em utilizar a vida de personagens históricas, literárias e bíblicas como ponto de partida para os seus roteiros.

Entre as conhecidas "mulheres fatais" de outros períodos, a mais retratada pela Sétima Arte foi Cleópatra que, sendo protagonista ou personagem secundária, aparece em dezesseis filmes. Depois, temos Salomé, que é tema ou coadjuvante em nove filmes, seguida por Messalina e Helena de Tróia, com oito filmes cada (PICKARD, 1988).

\begin{tabular}{|c|c|c|c|c|c|c|}
\hline EM TESE & BELO HORIZONTE & v. 19 & N. 2 & AG0.-OUT. 2013 & BOTTON. Teatro, ópera e cinema: Salomé, de mulher fatal a mulher objeto & P. 185-204 \\
\hline
\end{tabular}

\section{Crítica Literária, outras Artes e Midias}


Logicamente, falamos de "mulheres possivelmente fatais", pois em muitas destas histórias contadas pelo cinema, as mulheres deixaram de ser "fatais", dependendo da abordagem e da intenção do roteirista e / ou diretor.

Assim como na peça de Wilde, o episódio bíblico é apenas ponto de partida para o roteiro do filme de William Dieterle. Vejamos um breve resumo do filme, protagonizado por Rita Hayworth, que tem no elenco, além de Stewart Granger, como o Comandante Claudius, Charles Laughton (Rei Herodes), Judith Anderson (Rainha Herodias) e Alan Badel (João Batista).

O filme inicia com legendas explicando que, devido à devassidão em que vivia a corte de Herodes, a rainha Herodias, havia enviado a princesa Salomé para ser criada em Roma.

Em cena, mais tarde, no entanto, a princesa é banida da cidade por querer se casar com um senador romano, que a rejeita com medo de perder os seus direitos de cidadão. Salomé parte de volta para a casa na mesma galé em que vão Pôncio Pilatos e o comandante Claudius, um romano, mas já com "ares" bastante cristãos. O comandante tenta aproximar-se de Salomé; ela o rejeita dizendo que nunca mais se apaixonará por um romano. Mesmo assim, na cabine da princesa, Claudius toma Salomé nos braços e a beija.
O grupo chega ao palácio de Herodes e o rei fica encantado com a beleza da enteada. Herodias percebe a fascinação do rei e planeja usar a beleza de Salomé para que Herodes atenda aos seus incessantes pedidos para prender e matar o profeta. Salomé, ao saber que João Batista fala contra a sua mãe, pede a Claudius que o prenda, mas ele, que já está convertido, nega o pedido.

Herodias convence Salomé a dançar para o rei e pedir a morte de João Batista, mesmo sabendo que ao dançar para ele, ela se tornaria "uma propriedade do rei". Salomé faz tudo acreditando em sua mãe, mas Claudius a leva para conhecer o Batista e a princesa também acaba se convertendo. Salomé, invertendo os planos da mãe, tenciona dançar e pedir a libertação de João, mas não houve tempo para isso. Enquanto ela dança, Herodes faz uma oferta a Herodias por Salomé, que pede então a cabeça do profeta. A bandeja de prata interrompe a dança de Salomé, que promete nunca mais olhar para a mãe. Na cena final, Salomé e Claudius ouvem o sermão da montanha.

O filme pode ser analisado apropriadamente se partirmos da questão do "olhar masculino", que define e domina a imagem da mulher como objeto erótico. Temos então um processo de objetificação causado por esse olhar masculino. Vejamos de que maneira ele opera. Quando, no texto fílmico, um homem olha para uma mulher, o espectador é levado

\section{Critica Literária, outras Artes e Midias}


a identificar-se com esse olhar, identificação necessária para a efetivação do cinema, em que entra como fator decisivo toda a problemática do voyeurismo. Desta forma, a mulher torna-se objeto do olhar da personagem masculina e, em seguida, objeto do olhar do espectador (KAPLAN, 1995)

Este procedimento é patente no filme de Dieterle, assim como em quase todo o cinema da era clássica de Hollywood. Tome-se, por exemplo, a primeira aparição de Salomé. A princesa dança em uma sala cheia, porém sua dança é uma apresentação apenas para o pretendente romano, que a olha fixamente. Já Salomé não olha diretamente para ele, e mais, interrompe a dança quando ele se retira da sala.

O fenômeno se repete na maioria das cenas em que há diálogo entre Salomé e uma personagem masculina. Estas cenas, invariavelmente, são realizadas em plano americano (tomadas da região da cintura para cima) com Salomé de frente para a câmera a olhar um ponto superior indefinido, enquanto seu interlocutor fixa-a diretamente. O mesmo ocorre na cena em que Salomé dança para Herodes, na qual é reforçada a objetificação pela fala de Claudius: "A mulher que dança para o rei torna-se sua propriedade [= seu objeto]”.

Aliás, as duas cenas em que a princesa dança, para o pretendente romano e para Herodes, ressaltam a posição da mulher como espetáculo para o olhar masculino. Repare-se ainda que ela não dança simplesmente, mas sempre dança para alguém.

Assim, temos que o olhar, no cinema hollywoodiano clássico, está identificado com o homem, devido ao voyeurismo, "perversão ativa praticada principalmente por homens" (KAPLAN, 1995:33), que tem por objeto o corpo feminino (no caso, configurando o exibicionismo, complemento passivo do primeiro ${ }^{2}$.

A objetificação assume ainda outras facetas dentro do filme. Como por exemplo, veja-se com que facilidade o comandante Claudius toma nos braços a então "hostil" princesa e beija-a sem que ela ofereça a menor resistência. Ou ainda, os embates que ocorrem entre Claudius e Herodes, em que o primeiro assume uma postura de proteger Salomé de sua própria vulnerabilidade a outro tipo de homem.

O processo de objetificação da protagonista em Salomé vai às últimas consequências e, mesmo neste breve resumo apresentado, já a situação em que se dá o pedido da cabeça do Batista salta aos olhos. Se, na Bíblia, como vimos, Salomé é instigada pela mãe; se, em Wilde e em Strauss, não há motivo para o pedido; na obra de Dieterle, Salomé sequer participa da cena, sendo a própria mãe, Herodias, quem faz o pedido a Herodes:
2. Na mesma obra, Kaplan demonstra de que forma e em que casos ocorre o rompimento da identificação do espectador com o olhar masculino.
EM TESE
BELO HORIZONTE
v. 19
N. 2
AG0.-OUT. 2013
BOTTON. Teatro, ópera e cinema: Salomé, de mulher fatal a mulher objeto
P. $185-204$

\section{Crítica Literária, outras Artes e Mídias}


(durante a dança de Salomé)

Herodes (inebriado): Eu daria metade do meu reino... Herodias: Não, dê-me a cabeça do Batista.

(Herodes consente silenciosamente. Aparece, em instantes, a cabeça em um prato. Salomé, com um grito, interrompe a dança)

Salomé: Minha mãe, e pensar que sou tua carne e teu sangue. Nunca mais vou olhar para você.

Da mesma forma que nessa cena, em várias outras, Salomé deixa-se manipular, transformando-se em objeto, perdendo a posição de sujeito de suas ações. E, ainda mais, assume o silêncio diante do poder.

Vejamos mais duas cenas importantes. Todos os contatos de Salomé com Herodes são mediados por Herodias. A ra inha "manobra" Salomé com o intuito de aumentar o desejo de Herodes por ela. Herodias, na cena que descrevemos a seguir, dialogando com seu conselheiro, não esconde o propósito de utilizar a beleza de Salomé para um fim:
Herodias: O rei veio para conhecer minha bela filha

Micha: Bela?

Herodias: Como nenhuma outra.

Micha: Uma rara beleza no palácio?

Herodias: Vamos desperdiçar tal beleza ou usá-la para um propósito?

Micha: Estava me perguntando a mesma coisa.

Herodias (ć́nica): Não fiz tudo que pude para proteger minha filha do rei?

Micha: Tudo! Até mandou-a para Roma para afastá-la do rei.

Herodias: $\mathrm{O}$ apetite dele aumentou, agora que ela está por perto.

Micha: Aumentou bastante.

Herodias: Não posso usar a volta dela a meu favor?

Micha: É bem possível. Para o seu próprio bem, sugiro que não perca tempo em... usar esta vantagem.

Herodias: Sim, Micha.

Finalmente, temos a última cena do filme, que representa certa redenção e, ao mesmo tempo, um prêmio pelas "boas intenções" de Salomé, que afinal desejava "vender-se" para salvar João Batista. Junto com Claudius, ela assiste o Sermão da Montanha.

Sendo assim, de que modo poderíamos ver nesta leitura do filme de Dieterle, aquilo a que nos referimos como o medo do desconhecido feminino? 
3. É interessante observar que a própria Rita Hayworth sofreu esta opressão pela idealização. Comentando por que os seus casamentos não davam certo, ela resume: "Os homens se assustam, pois deitam com Gilda e acordam com Rita"
Aqui, dado que a personagem do filme é bastante diferente da Salomé, de Wilde, este "medo" encontra-se na própria estrutura do filme, que privilegia o olhar masculino, opressor e dominador (voyeurista ativo). No texto fílmico, a personagem feminina é idolatrada somente pela sua beleza, mas, de qualquer forma, a idealização é uma forma de opressão, posto que o desejo da mulher deve se anular para servir ao desejo de seu dominador. Em outras palavras, é negada à personagem uma voz ativa e um discurso próprio, e ainda colocando-a em uma posição em que o seu desejo está sujeito a um outro. Segundo Kaplan, a objetificação da mulher não possui como único objetivo a erotização: Do ponto de vista psicanalítico, ele (o processo de objetificação) é concebido para aniquilar a ameaça que a mulher (castrada e possuidora de um sinistro órgão genital) representa (KAPLAN, 1995: 54).

Neste ponto de vista, tanto a glorificação ou a idealização, quanto a depreciação, não passam da mesma necessidade de reprimir o medo do desconhecido, inspirado pela mulher.

Salomé reforça também o sistema patriarcal, ainda que a personagem forte do filme seja Herodias e não Herodes. Na verdade, as qualidades da rainha são as mesmas que fazem conhecidos os patriarcas. Como observa Kaplan, quando a mulher assume o "olhar", ela perde as características de bondade, humanidade e maternidade, tornando-se quase sempre fria, enérgica, ambiciosa e manipuladora, exatamente como os homens que para ela perderam a posição. Sendo assim, a estrutura patriarcal, em si mesma, permanece intacta, ainda que a figura central seja outra.

Até aqui, as comparações entre a Salomé, de Wilde e a de Dieterle são um tanto próximas: nas duas obras existe uma forma de representação do medo do desconhecido feminino e um posicionamento sobre a sociedade patriarcal, ainda que a obra de Wilde seja revolucionária por ir contra a sociedade da época e a de Dieterle, ao contrário, reforce a estrutura sua contemporânea. Mas a primeira Salomé é emblemática da arte decadentista. E a Salomé de Dieterle, pode ser emblemática também da arte de sua época?

Para responder a esta pergunta, temos que nos reportar, ainda que rapidamente, para o contexto da produção de Salomé, de Dieterle. Lançado nos cinemas americanos em 1953, Salomé é uma produção do final dos anos áureos de Hollywood, período que vai desde o começo do cinema falado até finais da década de 50. A indústria cinematográfica americana da época, situada praticamente toda ela nessa cidade, é a décima primeira indústria dos Estados Unidos, com faturamento superior a todas as redes de supermercados juntas; emprega cerca de trinta mil pessoas e produz aproximadamente quatrocentos filmes por ano. Segundo pesquisa de Ruy Castro: "cinquenta milhões de americanos viam pelo menos um filme por semana, todas as semanas,

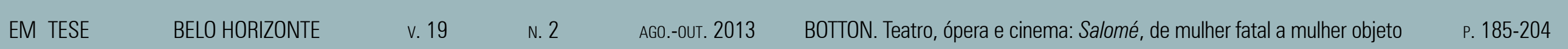

\section{Crítica Literária, outras Artes e Mídias}


deixando quase 700 milhões de dólares por ano nas bilheterias" (CASTRO, 1995: 81).

Mas o que nos interessa realmente, além destas cifra monstruosas, considerando ainda que se trata de um período conturbado da história mundial, é o esquema ou modelo fílmico do cinema clássico: "É o conceito de um modelo clássico, que segue convenções determinadas recorrentes em cada novo produto, o qual o público consequentemente espera e no qual confia” (KAPLAN, 1995: 29)

Em outras palavras, o cinema feito em Hollywood é a arte típica das culturas de massa, sem entrar aqui na discussão de mérito ou demérito que se embute neste termo, mas sim, na questão da transformação do objeto de arte em mercadoria.

A Arte, tanto na "alta cultura" quanto na cultura de massa pode ser entendida como uma "finalidade sem fim", isto é, "uma atividade orientada para uma meta que, não obstante, carece de propósito ou fim prático no 'mundo real' dos negócios, da política ou da práxis humana concreta em geral" (JAMESON, 1995: 11). Destarte, o "prazer estético" pode ser alcançado através de uma película como Cães de Aluguel, assim como em uma peça de Mozart, mas o que os diferencia é o conceito capitalista moderno de mercadoria, que leva à trilha da reificação pelo seu objetivo de consumo.
Os estúdios de Hollywood são indústrias participantes de um sistema que transforma tudo, inclusive a força de trabalho, em mercadoria, cujo único objetivo é ser consumida. $\mathrm{Ou}$ seja, a obra de arte, nesse sistema, é transformada em meio para um fim, ou seja, tudo que ela é só possui valor se puder ser consumida, ou ainda tudo que ela é, visa o seu consumo.

Dessa forma, o objeto artístico não possui valor qualitativo intrínseco, mas o possui apenas na medida em que possa ser utilizado (consumido). E é desta arte que a Salomé, de Dieterle, parece ser emblema. Ou seja, a beleza de Salomé só tem valor para Herodias (aqui, metaforizando a sociedade, a cidade, o que há de sedentário na civilização) se ela puder ser usada para tirar alguma vantagem (Herodias: Vamos desperdiçar tal beleza ou usá-la para um propósito?).

A personagem de Dieterle é, ainda, ao inverso da mulher fatal de Wilde, uma mulher objeto, manipulada para uma finalidade durante todo o filme, sendo, ironicamente recompensada pela mesma religião, cuja descrição de Camille Paglia apontamos no início desse trabalho, como uma das artimanhas do poder masculino para reprimir o culto do ventre. Sendo assim, identificamos a Salomé do filme como um emblema desta arte manipulada para confortar as massas (através de esquemas recorrentes) e que possui como finalidade primeira e última o consumo.

\section{Crítica Literária, outras Artes e Mídias}




\section{FECHAM-SE OS PANOS, APAGAM-SE AS LUZES}

Este trabalho procurou comparar três obras baseadas em um mesmo episódio bíblico, com o intuito de perceber de que forma este mesmo ponto de partida foi utilizado por diferentes épocas artísticas, servindo a interesses distintos.

Primeiramente procuramos estabelecer duas possibilidades de leitura que, na verdade, se complementam. Dado que a leitura que leva a falar no patriarcado dominante, pode ser explicada justamente pelo medo inspirado no homem pela mulher ou seja, este mesmo medo pode ser um dos fatores que levou o homem a criar um sistema que, por si só, já é repressivo.

Em seguida, a comparação entre as "Salomés" de Oscar Wilde, de Richard Strauss e de William Dieterle, procurou seguir as questões expostas na primeira parte, e acabou por chegar a algumas conclusões. Destacamos as obras de Wilde e de Strauss como uma arte revolucionária, por colocar-se em um posicionamento crítico em relação à sociedade de seu tempo, ainda que hoje o estereótipo da mulher fatal não seja bem aceito mesmo pelas feministas. Vimos também de que forma foi possível estabelecer a Salomé de Dieterle como uma emblematização da cultura de massa.

Enfim, muito embora todas as obras apresentem o mesmo ponto de partida, elas acabam por chegar a pontos bastante distintos entre si, fazendo com que a mesma personagem, em cada obra diferente, seja vista como uma síntese de sua própria época histórica e artística.

\section{REFERÊNCIAS}

\section{BIBLIOGRÁFICAS}

CASTRO, Ruy. Hollywood. In: LABAKI, Amir (org.). Folha conta cem anos de cinema. Rio de Janeiro: Imago, 1995: 81-87.

GOMES, Álvaro Cardoso. Salomé, Starlet Simbolista (Eugênio de Castro). In: $\mathbf{O}$ poético: magia e iluminação. São Paulo: Perspectiva, 1990: 67-88.

HAUSER, Arnold. A era do cinema. In: A História Social da Literatura e da Arte. São Paulo: Mestre Jou: 957-992.

JAMESON. Fredric. Reificação e Utopia na cultura de massa. In As marcas do visível. Tradução: João R. Martins Filho. Rio de Janeiro: Graal, 1995: 9-35.

KAPLAN, Elizabeth Ann. A mulher e o cinema: os dois lados da câmera. Tradução: Helen M. Potter Pessoa. Rio de Janeiro: Rocco, 1995

KOBBÉ, Gustave. O livro completo da ópera. Tradução: Clóvis Marques. Rio de Janeiro: Jorge Zahar Editores, 1997.

LEXICON, Herder. Dicionário de Símbolos. Tradução: Erlon J. Paschoal. 10ª edição. São Paulo: Cultrix, 1997.

\section{Crítica Literária, outras Artes e Mídias}


MAEDER, Edward (org.). Hollywood and history. USA: James and Hudson, 1987.

MORETTO, Fúlvia M.L. Caminhos do decadentismo francês. São Paulo: Perspectiva / Edusp, 1989

PAGLIA, Camille. Personas sexuais. São Paulo: Cia das Letras, 1991

PICKARD, Roy. Who played who on the screen. London:

Batsford, 1988.

SALES GOMES, Paulo Emílio. A personagem cinematográfica.

In.: CANDIDO, Antonio (org.). A personagem de ficção. $2^{a}$

edição. São Paulo: Perspectiva, 1968: 105-119.

STRAUSS, Richard. Salomé. Tradução: Mariana Portas. 2a edição.

São Paulo: Editora Moderna, 2011. (Coleção Grandes Óperas; v. 19)

WILDE, Oscar. Salomé. Tradução: João do Rio. Belo Horizonte: Itatiaia, 1989.

\section{FILMOGRAFIA}

SALOMÉ. Dir.: William Dieterle. Roteiro: Harry Kleiner. Intérpretes: Rita Hayworth; Stewart Granger; Alan Badel; Charles Laughton;

Judith Anderson. EUA: Columbia Pictures, 1953. 1 DVD (103 min.),

widescreen, color., legendado. 